\section{Arif Zainudin}

Dosen Ilmu Pemerintahan, FISIP Univer-

sitas Pancasakti Tegal

Email: arif_zainudin88@yahoo.com

\section{Suranto}

Dosen Magister IImu Pemerintahan Universitas Muhammadiyah Yogyakarta Email: suranto_umy@yahoo.com

http://dx.doi.org/10.18196/ jgpp.2014.0001

\section{Kebijakan Program} Pemberdayaan Masyarakat Industri: Studi Kasus Implementasi Program Tegal Bisnis

\begin{abstract}
The purpose of this study is to look at the impact of the implementation of the policy Business Tegal. In evaluating the program Business Tegal viewed from the aspect of productivity policy, financial efficiency and level of community satisfaction policy Business Tegal. By using a mixed method research approach hopes this research can include aspects of qualitative and quantitative. Based on the results of research carried out showed that the productivity of the policy can not boost industrial production and the quality of many of the home industry go bankrupt due to the government can not provide assistance in the form stimulant funds. Although the government has provided some training still can not help improve the quality of the industry because the training is not only limited to assisting the industry as expected by the public. With the impact, then the public is not satisfied about the implementation of the Business Tegal policy because no positive impact on the sustainability of the industry and welfare.

Keyword: Policy Implementation, Community Development, Tegal Business Programm
\end{abstract}

\begin{abstract}
ABSTRAK
Tujuan penelitian ini adalah untuk melihat dampak yang ditimbulkan oleh implementasi kebijakan Tegal Bisnis. Dalam mengevaluasi program Tegal Bisnis melihat dari aspek produktivitas kebijakan, efisiensi penggunaan anggaran dan tingkat kepuasan masyarakat mengenai kebijakan Tegal Bisnis. Dengan menggunakan pendekatan penelitian mix method harapannya hasil penelitian dapat mencakup aspek-aspek kualitatif dan kuantitatif. Berdasarkan hasil penelitian yang dilakukan menunjukkan bahwa produktivitas dari kebijakan tidak dapat mendongkrak kualitas produksi industri dan banyak home industry yang bangkrut diakibatkan pemerintah tidak dapat memberikan bantuan berbentuk stimulan dana. Walaupun pemerintah telah memberikan beberapa pelatihan tetap tidak dapat membantu meningkatkan kualitas industri karena hanya sebatas pelatihan tidak pendampingan industri seperti yang diharapkan oleh masyarakat. Dengan dampak tersebut, maka masyarakat tidak puas tentang implementasi kebijakan Tegal Bisnis karena tidak berdampak positif bagi kelangsungang industri maupun kesejahteraan.

Kata Kunci : Implementasi Kebijakan, Pemberdayaan Masyarakat, Program Tegal Bisnis
\end{abstract}

\title{
PENDAHULUAN
}

Mensejahterakan masyarakat adalah sebuah tugas pemerintah untuk melakukan sebuah perencanaan kebijakan yang strategis, sesuai dengan amanat UUD 1945 yakni perencanaan kebijakan pembangunan kesejahteraan masyarakat diselenggarakan dengan 
efektif, efisien dan terpadu. Kemudian berdasarkan tujuan pembentukan Negara Kesatuan Republik Indonesia yang tercantum dalam pembukaan UUD 1945 salah satunya ialah memajukan kesejahteraan umum. Indonesia dalam mewujudkan perencanaan pembangunan kesejahteraan masyarakat yang efektif maka diterapkan sistem otonomi daerah sesuai dengan amanah UU No. 32 tahun 2004 dan revisinya UU No.12 tahun 2008. Menurut G. Shabbir Cheema dan Dennis A. Rondinelli (Sidik Jatmika, 2001:33) subtansi dari penyelenggaraan otonomi daerah yakni bisa mengurus dirinya sendiri (daerah), baik dari sisi wewenang hukum, wewenang politik, wewenang pemerintahan, terutama wewenang ekonomi, dan wewenang kultural. Maksud dalam mengurus dirinya sendiri (daerah) adalah pemerintah daerah dalam melakukan tugas murni pemerintah dilakukan dengan mandiri sebab pelimpahan kewenangan sudah diberikan kepada setiap daerah.

Otonomi daerah diselenggarakan dengan bertujuan meningkatkan social capital atau penguatan kelembagaan sosial masyarakat, sehingga dalam proses perencanaan kebijakan pembangunan masyakat lebih terarah dan lebih fokus kepada kebutuhan masyarakat (Affendi Anwar, 2003:3). Kemandirian lembaga masyarakat sangat dibutuhkan dalam rangka membangun lembaga masyarakat yang benar-benar mampu menjadi wadah perjuangan kaum ekonomi, yang mandiri dan berkelanjutan dalam menyuarakan aspirasi serta kebutuhan mereka dan mampu memperngaruhi proses pengambilan keputusan yang berkaitan dengan kebijakan publik di tingkat lokal agar lebih berorientasi ke masyarakat miskin (pro poor) dan mewujudkan tata kepemerintahan yang baik (good governance), baik ditinjau dari aspek sosial, ekonomi maupun lingkungan (Sopandi : 2010). Perencanaan pembangunan pada hakekatnya harus dapat mencerminkan perubahan total suatu masyarakat atau penyesuaian sistem sosial secara keseluruhan, tanpa mengabaikan keragaman kebutuhan dasar dan keinginan individual 
maupun kelompok-kelompok sosial yang ada didalamnya, untuk bergerak maju menuju suatu kondisi kehidupan yang lebih serba baik, secara material maupun spiritual (Todaro, 2000:20). Untuk mencapai keberhasilan pembangunan tersebut Indonesia menerapkan sistem bottom-up sesuai dengan amanah UU No. 25 Tahun 2004 tentang sistem perencanaan pembangunan nasional. Sistem bottom-up maka pemerintah daerah dalam merencanakan kebijakan pembangunan lebih dapat efektif, efisien dan produktif. Menurut Korten (1984), masa pasca industri akan menghadapi kondisi-kondisi baru yang sama sekali berbeda dengan kondisi di masa industri, di mana potensi-potensi baru penting dewasa ini memperkokoh kesejahteraan, keadilan, dan kelestarian umat manusia. Titik pusat perhatianya adalah pada pendekatan ke arah pembangunan yang lebih berpihak kepada rakyat.

Sebagai bentuk program pemerintah yang direncanakan bottomup ialah BLT (Bantuan Langsung Tunai) berdasarkan kajian yang dilakukan oleh SMERU (2010) mengemukakan bahwa perencanaan program BLT dilandasi oleh kenaikan BBM pada waktu itu yang signifikan sehingga untuk menstabilkan perekonomian masyarakat pemerintah merencanakan program untuk mengatasi permasalahan yang diakibatkan dampak kenaikan BBM. Namun program BLT ini belum optimal dapat mengatasi kesejahteraan masyarakat secara menyeluruh, karena program BLT ini hanya diberikan sementara 3 buln setelah kenaikan harga BBM. Persoalan yang paling dasar ialah pengangguran yang menciptakan kemiskinan massal. Berdasarkan masterplan pembangunan pemerintah RPJP 2009-2025 perencanaan secara global yakni mengatasi kemiskinan dengan meningkatkan lapangan pekerjaan.

Lapangan pekerjaan menjadi salah satu indikator keberhasilan sebuah pembangunan kesejahteraan masyarakat di suatu negara (Todaro, 2000:20). Namun permasalahan di Indonesia bukan hanya lapangan pekerjaan namun upah minimun regional yang sangat 
berkaitan dengan kesejahteraan masyarakat. Perencanaan yang bersifat bottom-up diharapkan dapat mengatasi permasalahan kesenjangan kesejahteraan masyarakat, dengan dasar permasalahan tersebut Kepala Daerah Kota Tegal memberikan kebijakan program mengenai peningkatan kesejahteraan masyarakat. Program kesejahteraan masyarakat dikenal sebagai Program Tegal Bisnis, dengan adanya program tersebut diharapkan pemerintah dapat mengoptimalkan sektor industri UMKM Kota Tegal sehingga kesejahteraan masyarakat sektor industri dapat optimalkan. Program Tegal Bisnis mempunyai sasaran utama yakni (1) membuka seluas-luasnya lapangan pekerjaan di Kota Tegal, (2) Meningkatkan eksistensi dan memberdayakan UMKM di Kota Tegal, dan (3) Meningkatkan nilai investasi Kota Tegal.

Melihat uraian tersebut peneliti mengkaji tentang efektifitas program pemerintah Kota Tegal dan menjawab pertanyaan mengenai apakah Program Tegal Bisnis dapat mengatasi kesenjangan kesejahteraan masyarakat di sektor industri?

\section{KERANGKA TEORI}

\section{PERENCANAAN PEMBANGUNAN DAERAH}

Pada umumnya suatu tujuan dan sasaran yang diharapkan akan lebih mungkin terwujud apabila sebelumnya telah dilakukan perencanaan dan persiapan yang matang untuk menyiapkan kebijakan tersebut. Perencanaan pembangunan menurut W.J.S Poewardarminta dalam bukunya kamus umum bahasa Indonesia bahwa yang dimaksud dengan "rencana" dalam hal ini dapat diartikan sebagai rancangan (rangka sesuatu yang akan dikerjakan). Pembangunan diartikan sebagai proses perubahan sosial dengan partisipatori yang luas dalam suatu masyarkat yang dimaksudkan untuk mencapai kemajuan sosial dan material (Rogers, 1983:25). Maka berdasarkan pendapat tersebut perlu pembagian fungsi tugas pemerintah dalam perencanaan pembangunan sehingga pemerintah 
dalam aktifitas kinerja akan terfokus kepada sasaran yang ingin dicapai sesuai dengan RPJP/RPJM/D.

\section{TABEL 1 PARADIGMA PEMBANGUNAN BERDASARKAN PEMBATASAN TUGAS PEMERINTAH MENURUT WORLD BANK (1997)}

\begin{tabular}{|c|c|c|c|c|}
\hline & \multirow{2}{*}{\multicolumn{3}{|c|}{ MENGATASI KEGAGALAN PASAR }} & \\
\hline & & & & $\begin{array}{l}\text { MEMPERBAIKI } \\
\text { PEMERATAAN }\end{array}$ \\
\hline Fungsi Minimal & \multicolumn{4}{|c|}{$\begin{array}{l}\text { Penyediaan Barang Publik Murni } \\
\text { - } \quad \text { Pertahanan dan keamanan } \\
\text { - } \quad \text { Hukum dan ketertiban } \\
\text { - } \quad \text { Mengatur Property Right } \\
\text { - } \quad \text { Manajemen ekonomi makro } \\
\text { Kesehatan masyarakat }\end{array}$} \\
\hline Fungsi Fasilitasi & $\begin{array}{l}\text { Mengatasi Eksternalitas } \\
\text { - Pendidikan dasar } \\
\text { - Perlindungan } \\
\quad \text { lingkungan }\end{array}$ & $\begin{array}{l}\text { Mengatur Monopoli } \\
\text { - Pengaturan utilitas } \\
\text { - Kebijakan antitrust }\end{array}$ & $\begin{array}{l}\text { Mengatasi } \\
\text { Imperfeksi Informasi } \\
\text { - } \quad \text { Asuransi } \\
\text { (Kesehatan, } \\
\text { jaminan hari } \\
\text { tua, pensiun) } \\
\text { - } \quad \text { Perlindungan } \\
\text { konsumen } \\
\end{array}$ & \\
\hline Fungsi Aktif & $\begin{array}{l}\text { Mengkoordinasikan Aktifi } \\
{ }^{*} \text { Mengembangkan Ekono } \\
{ }^{*} \text { Mengelompokkan Gaga }\end{array}$ & $\begin{array}{l}\text { Swasta } \\
\text { Pasar }\end{array}$ & & $\begin{array}{l}\text { Redistribusi } \\
{ }^{*} \text { Redistribusi Asset }\end{array}$ \\
\hline
\end{tabular}

Sumber : World Bank Development Report (1997, table1.1, p:27)

Berdasarkan UU No. 25 tahun 2004 tentang sistem perencanaan nasional, sistem perencanaan pembangunan di Indonesia membuka ruang partisipasi bagi masyarakat melalui kegiatan musrenbang kegiatan ini dimaksudkan untuk singkronisasikan program pemerintah dengan kebutuhan masyarakat.

Beberapa dokumen yang dijadikan landasan perencanaan pembangunanan daerah. Seperti RPJP Nasional / Daerah berlaku sampai 20 tahun, RPJMNasional / Daerah sampai dengan 5 tahun, RKP dan RKPD berlaku 1 tahun. Dalam sistem perencanaan pembangunan keterkaitan dengan sistem penganggaran sebuah rangkaian yang tidak terputus, karena dokumen untuk penganggaran berpedoman dengan RKP dan Renja SKPD sehingga penganggaran berbasis kinerja. 


\section{EFEKTIVITAS}

Pada dasarnya pengertian efektivitas menunjukkan pada taraf hasil, sering atau senantiasa dikaitkan dengan pengertian efisien meskipun sebenarnya ada perbedaan diantara keduanya. Menurut Barnard (dalam Nurudin,2007:25) menjelaskan bahwa arti efektif dan efesien.

"when specific desired and is attained we shall say that the action is efective. When the unsought consequences of the action are more important than the attainment of the desired and are dissatifactory, effective action, we shall say, it is inefficient. When the unsought consequences are unimportant or trivial, the action is efficient. Accordingly, we shall say that an action is effective if it specific objective aim.it is satisfies the moyivates of the aim, whatever it is effective or not".

Menurut Drucket, menyatakan bahwa "effective is to do the right things : while efficiency is to do the things right". Melihat dari pendapat yang telah diuraikan maka efektif lebih mengarah kepada pencapaian sasaran, sementara efisien mengarah kepada kemampuan menggunakan sumber daya yang ada secara baik (tidak berlebihan) untuk mencapa produktifitas yang optima. (Nurudin, 2007:26)

Strees dalam Tangkilisan (2005:141) mengemukakan 5 kriteria dalam pengukuran efektivitas, yaitu Produktivitas, kemampuan adapsi kerja, Kepuasan kerja, kemampuan berlaba dan pencarian sumber daya. Dalam kajian evaluasi kebijakan publik maka pertimbangan yang paling utama ialah waktu pelaksanaan atau implementasi, efisien, kepuasan dan pengembangan. Pertimbangan ini didukung oleh pendapat Gibson (1996:50) bahwa krieteria efektifitas yaitu :

a. Produktifitas

b. Efisiensi

c. Kepuasan

Menurut Manpower Service Commision (MSC), efektivitas didefinisikan sebagai pengukuran terhadap ketercapaian tujuan yang 
telah ditetapkan sebelumnya. Suatu kegiatan dapat dikatakan efektif jika outpunya sama atau sesuai dengan yang telah ditetapkan dan jika tidak sesuai maka kegiatan tersebut tidak efektif (Suhana,1998:15). Penilaian efektifitas program perlu dilakukan untuk menemukan informasi tentang manfaat dan dampak yang ditimbulkan oleh program, untuk melihat dampak yang diakibatkan maka melalui indikator produktifitas, efisien, dan kepuasan Stakeholder (penerima/pemakai) (Cambel J.P)

\section{IMPLEMENTASI PROGRAM}

Di dalam mepelajari masalah implementasi kebijakan berarti berusaha untuk memahami apa yang senyatanya terjadi sesudah atau program dijalankan atau dirumuskan, yakni peristiwa-peristiwa dan kegiatan yang terjadi seteah proses pengesahan kebijakan negara, baik itu menyangkut usaha pengadministrasian maupun juga usaha untuk memberikan dampak tertentu pada masyarakat ataupun peristiwa (Mazmanian dan Sabatier,1981:123). Berdasarkan dari teori tersebut maka implementasi dalam bentuk program ada beberapa langkah yang harus diperhatikan sehingga tujuan kebijakan/program dapat tercapai. Sedangkan Lane (1993:102) mengemukakan bahwa konsep implementasi memiliki dua aspek, yaitu :

a. Hubungan antara tujuan (objective) dan hasil (outcomes), sisi tanggungjawab (responsibility side);

b. Proses untuk membawa kebijakan ke dalam efek yang merupakan sisi kepercayaan (trust side).

George Edward III $(1980,1)$ menegaskan bahwa masalah utama administrasi publik adalah "Lack of attention to implementaion". Dikatakannya, without effective implementation the decission of policy makers will not be carried out successfully. Dalam penelitian yang mengkaji tentang efektifitas kebijakan maka menurut Edward harus memperhatikan faktor - faktor yang mempengaruhi implementasi kebijakan. Menurut Edward, communication, resource, disposition or 
attitudes, dan bureaucratic structures. Dengan demikian Implementasi adalah sebuah proses interaksi antara penentuan tujuan dan tindakan untuk mencapai tujuan. Ini pada dasarnya adalah kemampuan untuk membangun hubungan dalam mata rantai sebab akibat agar kebijakan bisa berdampak (Parsons, 2005;466).

Komunikasi berkenaan dengan bagaimana kebijakan dikomunikasikan pada organisasi dan publik dan sikap serta tanggapan dari pihak yang terlibat. Resources berkenaan dengan ketersediaan sumber daya pendukung, khususnya sumber daya manusia. Hal ini berkenaan dengan kecakapan pelaksana kebijakan publik untuk carry out kebijakan secara efektif. Disposition berkenaan dengan kesediaan dari para implementator untuk carry out kebijakan publik tersebut. Kecakapan saja tidak mencukupi, tanpa kesediaan dan komitmen untuk melaksanakan kebijakan. Struktur birokrasi berkenaan dengan kesesuaian organisasi birokrasi yang menjadi penyelenggara implementasi kebijakan publik. Tantangannya adalah bagaimana agar tidak terjadi bureaucratic fragmentation karena struktur ini menjadi proses implementasi menjadi jauh dari efektif.

Berdasarkan kontruksi kebijakan publik Kota Tegal dalam hal ini untuk kelancaran implementasi program yang lebih efektif. Maka dibutuhkan faktor-faktor yang dapat mempengaruhi program tersebut sehingga berjalan sesuai dengan tujuan umum program tersebut. Oleh karena itu faktor komunikasi, SDM, Disposisi perintah, dan struktur birokrasi sangat dibutuhkan untuk pelaksanaannya.

\section{METODE PENELITIAN}

Dalam penelitian ini peneliti menggunakan metode penelitian mix-method atau metode campuran. Penelitian mix-method ialah penggabungan metode observasi dan wawancara yang berkaitan dengan data kualitatif, dengan metode survei tradisional (data kuantitatif) (Sieber dalam John Creswell 2014:21). Pengambilan metode ini didasari oleh peneliti karena berkaitan dengan data 
dinamis, pertanyaan terbuka dan pertanyaan tertutup, bentuk data berganda yang membuka kemungkinan untuk digali lebih dalam, analisis statistik yang digabungkan dengan analisis tekstual, dan lintas-interprestasi data base.

Untuk membatasi pembahasan agar tetap fokus terhadap permasalahan maka peneliti menentukan indikator penelitian, antara lain :

a. Produktifitas Program Tegal Bisnis, dengan kriteria tingkat kesejahteraan masyarakat industri, lapangan pekerjaan, pengembangan kualitas UMKM, dan nilai investasi daerah.

b. Efisiensi penggunaan anggaran dan ketepatan waktu, dengan kriteria penggunaan anggaran, dan kesesuaian waktu pelaksanaan program penunjang.

c. Kepuasan terhadap implementasi program Tegal Bisnis.

Untuk mendapatkan hasil yang komprehensif peneliti akan mengkombinasikan dengan faktor determinan implementasi program, faktor tersebut diantara lain sebagai berikut :

a. Komunikasi (Sosialisasi)

b. Sumber Daya Manusia

c. Struktur Birokrasi

d. Sistem Disposisi Kewenangan (George Edward III, 1980:148)

Sedangkan untuk pemberian skor terhadap indikator penelitian maka diuraikan sebagai berikut :

a. Produktivitas (40\%)

Kriteria penilaian sebagai berikut :

- $10 \% \Rightarrow$ Tidak efektif

- $20 \% \Rightarrow$ kurang efektif

- $30 \% \Rightarrow$ Efektif

- $40 \% \Rightarrow$ Sangat Efektif

b. Efisien (30\%)

- $10 \% \Rightarrow$ Tidak Efisien 
- $20 \%=>$ Cukup Efisien

- $30 \% \Rightarrow$ Efisien

c. Kepuasan $(30 \%)$

- $\quad 1,00-1,75$ Tidak Puas

- $\quad 1,76-2,50$ cukup puas

- 2,51-3,25 puas

- $3,26-4,00$ sangat puas

\section{PEMBAHASAN}

\section{KEBIJAKAN TEGAL BISNIS}

Penyusunan rencana pembangunan daerah periode 2009 - 2014 didasarkan pada visi, misi, dan program pasangan Walikota dan Wakil Walikota Tegal yang terpilih pada pemilihan umum 2009. Kemudian rencana pembangunan tertuang pada RPJMD Kota Tegal Tahun 2009 - 2014 selanjutnya menjadi pedoman dalam menyusun rencana strategis SKPD.

Selanjutnya pembangunan Kota Tegal memberikan arah dan tujuan untuk mewujudkan cita - cita dan tujuan pembangunan daerah sesuai dengan visi, misi dan program Walikota. Arah pembangunan Kota Tegal tertuang pada RPJMD Kota Tegal 2009 2014, yang merupakan penjabaran dari visi, misi dan program Walikota yang penyusunannya berpedoman pada RPJPD Kota Tegal Tahun 2005 - 2025 dan memperhatikan RPJM Provinsi Jawa Tengah serta RPJM Nasional, yang memuat arah dan kebijakan keuangan daerah, strategi pembangunan daerah, kebijakan umum dan program Satuan Kerja Perangkat Daerah (SKPD) disertai rencana kerangka pendanaan yang bersifat indikatif.

Pembangunan Kota Tegal tahun 2009 - 2014 akan mencakup beberapa program yakni : (a) Tegal Sehat, (b) Tegal Cerdas, (c) Tegal Bisnis, (d) Tegal Maritim, (b) Tegal Wisata. Program yang telah ditetapkan dan tertuang di PERDA 6 tahun 2009 tentang RPJMD Kota Tegal, didasari oleh rencana program kerja kepala daerah yang 
disesuaikan dengan RPJM Provinsi Jawa Tengah.

Pada tahun 2009 kota Tegal mempunyai arah kebijakan tentang memperkuat kota Tegal sebagai kota industri. Menguatkan Kota Tegal sebagai sentra industri logam dan mesin, predikat ini perlu terus dipertahankan dengan mengembangkan tidak hanya terbatas pada logam dan mesin saja namun juga produk - produk lainnya misalnya tekstil dan produk tenun, industri kerajinan, batik tegalan maupun industri lainnya. Sehingga akselerasi pembangunan perekonomian kota Tegal dapat berjalan dengan lancar. Dengan arah kebijakan tersebut, maka pemerintah membuat program unggulan yang dijadikan sebagai acuan dasar kebijakan.

Pada akhir tahun 2009 langkah pertama dalam implementasi kebijakan Tegal Bisnis, yang dimulai dari pelatihan yang diberikan oleh DISPERINDAGKOP Kota Tegal. Penerapan Kebijakan Program Tegal Bisnis pada tahun 2009 hingga tahun 2014. Pendanaan program pendukung kebijakan ini diatur melalui APBD pada tiap tahunnya. Total pendanaan kebijakan ini sebesar Rp. 5.491.638.000,

Berdasarkan arah kebijakan untuk menguatkan potensi industri dan menggerakkan roda perekonomian kota Tegal, maka walikota meluncurkan Program Tegal Bisnis. Makna dari Tegal Bisnis itu sendiri adalah suatu kondisi dimana pada tahun 2012 diharapkan masyarakat Kota Tegal dapat menjalankan aktifitas bisnis dan ekonomi secara optimal baik sektor riil maupun jasa, sehingga tercapai peningkatan pendapatan, kemandirian, dan kesejahteraan masyarakat.

Dengan terwujudnya iklim yang dapat mendorong masyarakat Kota Tegal untuk menjalankan roda bisnis dan ekonomi secara optimal baik sektor riil maupun jasa dengan dukungan berbagai komponen masyarakat dan pemerintah Kota Tegal, diharapkan pendapatan masyarakat akan meningkat yang pada gilirannya masyarakat Kota Tegal akan semakin sejahtera dan memiliki kemandirian secara ekonomi. 
Program Tegal Bisnis mempunyai beberapa sasaran yang dijadikan indikator keberahasilan. Terbagi menjadi 2 sasaran yakni sasaran umum dan sasaran khusus, antara lain sebagai berikut ini : Sasaran Umum adalah Membangun dan menumbuh kembangkan semangat kebersamaan, kegotongroyongan seluruh pemangku kepentingan (stakeholder) untuk secara sinergis membangun perekonomian daerah guna melayani pengangguran,kemiskinan dan ketertinggalan dan Sasaran Khusus untuk Menciptakan iklim kondusif bagi investasi, Menciptakan peluang usaha untuk mendorong tumbuhnya usaha baru, meningkatkan percepatan pertumbuhan ekonomi secara berkualitas, Meningkatkan kapasitas manajemen dan akses permodalan bagi pengembangan UMKM dan Koperasi.

Kebijakan pencapaian dimaksudkan sebagai upaya untuk mewujudkan Tegal Bisnis. Kebijakan pencapaian tersebut dilakukan berdasarkan hasil analisa secara menyeluruh terhadap permasalahan - permasalahan dalam pembangunan ekonomi Kota Tegal. Permasalahan - permasalahan tersebut harus dapat diatasi secara tepat dan profesional melalui upaya - upaya kebijakan pencapaian Tegal Bisnis sebagai berikut :

a. Meningkatkan Investasi Daerah dan Iklim Usaha Melalui Pemberian Insentif di Bidang Perijinan.

Kebijakan di bidang perizinan yang akan dilakukan adalah sebagai berikut :

- Pemberian insentif bagi UMKM yang mengajukan perizinan baru dan perpanjangan ijin usaha.

- Pemberian insentif bagi investor yang bermitra dengan UMKM, pemberian keringanan bagi usaha ekonomi lemah serta pemberian insentif pada kegiatan usaha strategis.

- Dalam upaya menciptakan iklim usaha yang kondusif dan untuk menarik investor dalam negeri maupun luar negeri, baik reinvestasi atau investasi baru, maka diperlukan Perda 
Pemberian Insentif dan Keringanan untuk mendorong pertumbuhan investasi. Insentif adalah sesuatu yang member dorongan atau yang memberi semangat atau perangsang untuk bertindak. Bentuk insentif dapat berupa Keringanan Pajak Daerah dan atau Retribusi Daerah.

- Penerapan Perijinan secara Online dan standar ISO.

b. Meningkatkan Produktifitas dan Daya Saing Produk UMKM Melalui Pemberdayaan Ekonomi dan Masyarakat

Untuk membangun ekonomi nasional yang tangguh dan mandiri dapatdicapai melalui pemberdayaan ekonomi dan masyarakat. Secara praktis upaya yang merupakan pengerahan sumber daya untuk mengembangkan potensi ekonomi rakyat ini diarahkan untuk meningkatkan produktifitas rakyat sehingga baik sumberdaya manusia maupun sumber daya alam disekitar keberadaan rakyat dapat di tingkatkan produktifitasnya. Dengan demikian, rakyat dan lingkungannya mampu secara partisipatif menghasilkan dan menumbuhkan nilai tambah ekonomis. Dalam pemberdayaan masyarakat dapat dilihat dari 3 sisi, yaitu: 1. Enabling adalah menciptakan suasana atau iklim yang memungkinkan potensi masyarakat berkembang. 2. Empowering adalah memperkuat potensi yang di miliki masyarakat. 3. Protection adalah proses pemberdayaan harus di cegah yang lemah menjadi semakin lemah sehingga harus tetap melindungi masyarakat yang lemah. Adapun upaya-upaya pemberdayaan ekonomi masyarakat dalam program Tegal Bisnis, antara lain :

- Fasilitasi kemitraan bagi usaha mikro kecil;

- Penyelenggaraan pendidikan pelatihan untuk UMKM yang disertai dengan bantuan bahan dan peralatan;

- Upaya penciptaan lapangan kerja baru;

- Fasilitasi permodalan bagi UMKM melalui KUR; 
- Meningkatkan promosi, distribusi dan jaringan informasi pemasaran;

- Menciptakan budaya penggunaan produk dalam negeri;

- Penguatan kelembagaan sentra-sentra di Kota Tegal melalui pembentukan KUB (Kelompok Usaha Bersama);

- Peningkatan perlindungan terhadap konsumen;

- Optimalisasi sarana prasarana penunjang perekonomian masyarakat.

c. Meningkatkan Pertumbuhan Ekonomi Melalui Penciptaan Iklim

Usaha yang Kondusif

Pertumbuhan ekknomi adalah suatu kondisi dimana terjadinya perkembangan Gross National Product (GNP) yang mencerminkan adanya pertumbuhan output perkapita dan meningkatnya standar hidup masyarakat. Adanya pertumbuhan ekonomi sangat penting karena dapat mempengaruhi hal-hal berikut :

- Tingkat kesejahteraan, masyarakat dikatakan makin sejahtera jika setidak-tidaknya output nasional perkapita meningkat.

- Kesempatan kerja, adanya pertumbuhan ekonomi yang jelas sangat membuka kesempatan kerja bagi seluruh factor produksi.

- Distribusi pendapatan.

Pertumbuhan ekonomi dapat juga diharapkan untuk memperbaiki distribusi pendapatan yang lebih merata. Tanpa adanya pertumbuhan ekonomi, yang ada hanyalah pemerataan kemiskinan. Upaya pemerataan pendapatan untuk meningkatkan kesejahteraan dapat berupa :

- Meningkatkan pertumbuhan ekonomi, menerapkan kebijakan-kebijakan moneter dan kebijakan fiscal yang dapat menaikkan daya beli masyarakat;

- Memperluas kesempatan kerja; 
- Meningkatkan produktifitas;

Dengan memperluas kesempatan kerja, maka akses masyarakat untuk memperoleh penghasilan semakin besar. Faktor-faktor yang akan menunjang pertumbuhan ekonomi adalah sebagai berikut :

- Sumber Daya Manusia, berupa kualitas tenaga kerja yaitu keterampilan, pengetahuan dan disiplin kuat akan meningkat pula pertumbuhan ekonomi;

- Sumber Daya Alam, seperti luas tanah, kesuburan tanah, keadaan iklim dan cuaca, hasil hutan, hasil laut, dan lainlain;

- Sumber Daya Modal, dapat disebut barang modal berupa uang dan social overhead capital seperti jalan, irigasi, sarana dan prasarana lainnya;

- Teknologi dan inovasi, yang dapat memberikan efek positif berupa efisiensi produksi, penemuan barang-barang baru dan peningkatan mutu;

Dengan adanya pertumbuhan yang tinggi, maka akan terjadi pemerataan hasil-hasil dari pertumbuhan ekonomi itu sendiri. Pemerataan disini bukan sekedar membagi kue yang sudah besar, melainkan yang lebih penting sejauh mungkin melibatkan rakyat dalam keseluruhan pembangunan ekonomi melalui kepemilikan asset dan akses. Pemerataan ekonomi dalam hal pemenuhan kebutuhan pokok seperti bahan makanan, pakaian, kebutuhan pokok lainnya dan juga pendapatan penduduk sendiri sangat di pengaruhi pertumbuhan ekonomi itu sendiri. Sedangkan dalam hal pembangunan dengan pertumbuhan ekonomi yang tinggi maka pemerataaan pembangunan akan mendorong pembangunan daerah melalui otonomi. Dalam hal pemerataan pembangunan dan pemerataan ekonomi yang harus di ratakan adalah prosesnya, bukan sekedar hasilnya, walaupun hal tersebut memerlukan konsekuensi kemajuan di berbagai sektor. 


\section{PRODUKTIVITAS KEBIJAKAN}

Secara umum, produktivitas diartikan sebagai pengaruh antara hasil nyata maupun fisik (barang-barang dan jasa). Menurut Whitmore mengemukakan bahwa produktivitas sebagai ukuran atas penggunaan sumber daya dalam suatu organisasi yang biasanya dinyatakan sebagai rasio dari keluaran yang dicapai dari sumber daya yang digunakan. Produktivitas Kebijakan Tegal Bisnis dapat diketahui melalui tingkat kesejahteraan masyarakat industri, lapangan pekerjaan sektor industri, pengembangan kualitas UMKM, dan nilai investasi daerah.

Menurut Tadjoeddein (2011) untuk melihat tingkat kesejahteraan masyarakat dalam suatu daerah dapat melalui nilai PDRB. Pelaksanaan Kebijakan Tegal Bisnis dimaksudkan untuk meningkatkan nilai PDRB khususnya dalam sektor industri dan perdagangan. Perkembangan nilai PDRB Kota Tegal setelah dilaksanakan Kebijakan Tegal Bisnis dapat dilihat dalam grafik berikut ini.

GRAFIK 1. PERKEMBANGAN NILAI PDRB KOTA TEGAL (ANGKA DALAM \%)

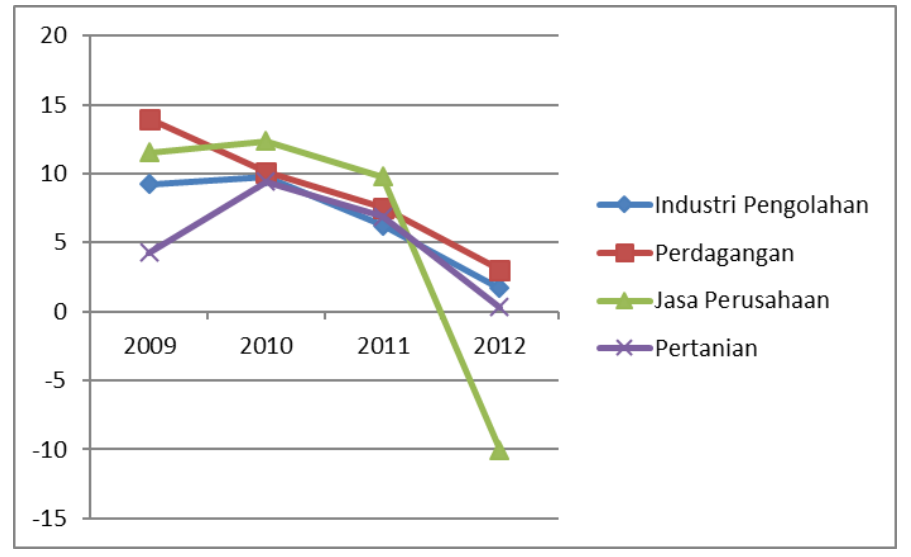

Sumber : Data Primer, 2013

Berdasarkan grafik 1, beberapa sektor pada saat tahun 2012 mengalami siklus penurunan hingga $10 \%$ dalam bidang jasa 
perusahaan, melihat dari tujuan Kebijakan Tegal Bisnis dalam optimalisasi perdagangan industri perusahaan dan industri kecil dapat dinilai tidak tercapai sesuai rencana. Menurunnya angka PDRB secara langsung dipengaruhi oleh sektor lapangan pekerjaan dan jumlah serapan tenaga kerja dalam unit usaha. Menurut Doly D Siregar, mengungkapkan untuk melihat peningkatan lapangan pekerjaan dan jumlah lapangan usaha bidang umkm dapat dilihat melalui 2 aspek yakni jumlah SIUP yang telah diterbitkan dan jumlah serapan tenaga kerja tiap unit usaha.

Adapun perkembangan perusahaan/unit usaha menurut jenis industri di Kota Tegal dapat dilihat dalam grafik berikut ini.

GRAFIK 2. PERKEMBANGAN UNIT USAHA MENURUT JENIS INDUSTRI KOTA TEGAL BERDASARKAN JUMLAH TERBITAN SIUP DAN PERPANJANGAN SIUP 2012 (ANGKA DALAM \%)

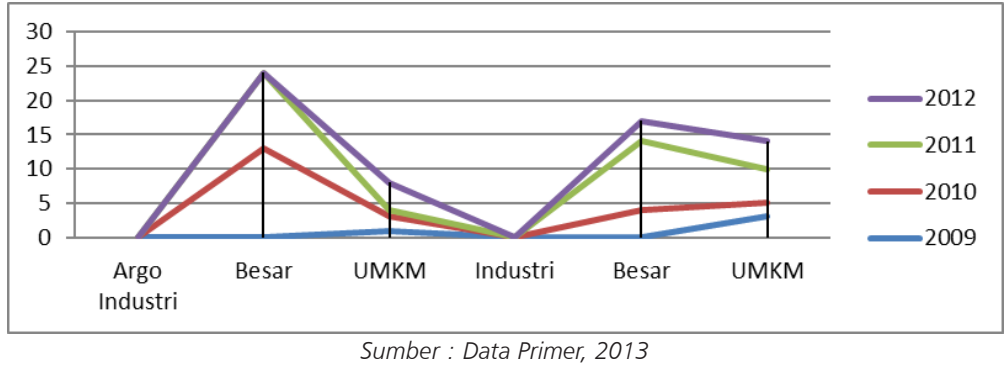

Berdasarkan grafik 2, mengungkapkan ada penurunan di sektor argo industri dan industri (logam). Penurunan yang tidak terlalu siginifikan dalam sektor argo industri dan industri dengan skla besar, jumlah unit usaha mengalami penurunan yang tidak terlalu siginifikan. Namun berbeda dengan unit usaha kecil (UMKM) terjadi penurunan yang siginifikan mencapai 11\% hingga tahun 2012. Maka dapat disimpulkan kebijakan Tegal Bisnis tidak berdampak positif dalam meningkatkan jumlah lapangan usaha masyarakat.

Menurunnya jumlah unit usaha di Kota Tegal disebabkan oleh rendahnya kualitas produksi oleh unit usaha sehingga daya minat beli masyarakat rendah dan jaringan pemasaran produk yang tidak 
didukung oleh pemerintah. Dalam upaya meningkatkan kualitas produksi usaha pemerintah Kota Tegal mengadakan pelatihan dengan jenis sebagai berikut : (1) pelatihan kemampuan industri berbasis teknologi, (2) fasilitasi pelatihan pengolahan ikan dan pengasapan, telur asin. (3) fasilitasi industri seperti pelatihan batik tulis asli Tegal.

Pelatihan yang diselenggarakan oleh pemerintah bekerja sama dengan balai diklat untuk meningkatkan kualitas produktifitas hasil industri UMKM. Para peserta dalam pelatihan tersebut ialah para pemilik usaha dan pekerja yang sudah terdaftar pada DISPERINDAGKOP Kota Tegal. Dengan adanya pelatihan industri, akan memunculkan daya beli konsumen yang produktif sehingga investasi dalam unit usaha akan meningkat.

\section{GRAFIK 3. PERKEMBANGAN NILAI INVESTASI KOTA TEGAL}

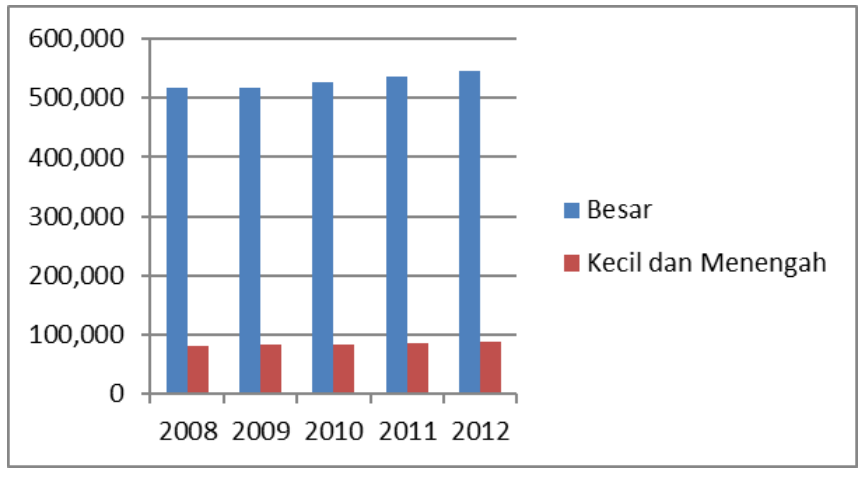

Sumber : Data Primer, 2013

Investasi menurut Fitz Gerald (1978) yaitu aktifitas berkaitan dengan usaha penarikan sumber-sumber yang dipakai untuk mengadakan modal barang pada saat sekarang ini. Kebijakan Tegal Bisnis dimaksudkan untuk mendatangkan para investor untuk menanamkan modal pada industri kecil maupun besar. Dalam mewujudkan tujuan tersebut sebagai leading sectoral yaitu Badan Pelayanan Perijinan Terpadu (BP2T) Kota Tegal memberikan kemudahan kepada setiap para investor namun sesuai dengan 
kriteria yang telah ditentukan. Adapun nilai perkembangan investasi Kota Tegal sebagai berikut (Grafik 3):

Berdasarkan grafik 3 diuraikan bahwa nilai investasi untuk industri kecil dan menengah mencapai puncaknya sebesar Rp. 86.546.000, dan untuk industri besar mencapai puncaknya sebesar Rp. 546.266.000,-. Dapat diasumsikan bahwa Kebijakan Tegal Bisnis masih didominasi oleh industri skala besar karena sesuai dengan fasilitas yang digunakan oleh industri tersebut. Adapun prosentase produktivitas investasi Kota Tegal digambarkan dalam grafik berikut ini.

GRAFIK 4. PROSENTASE PRODUKTIVITAS INVESTASI KOTA TEGAL (\%)

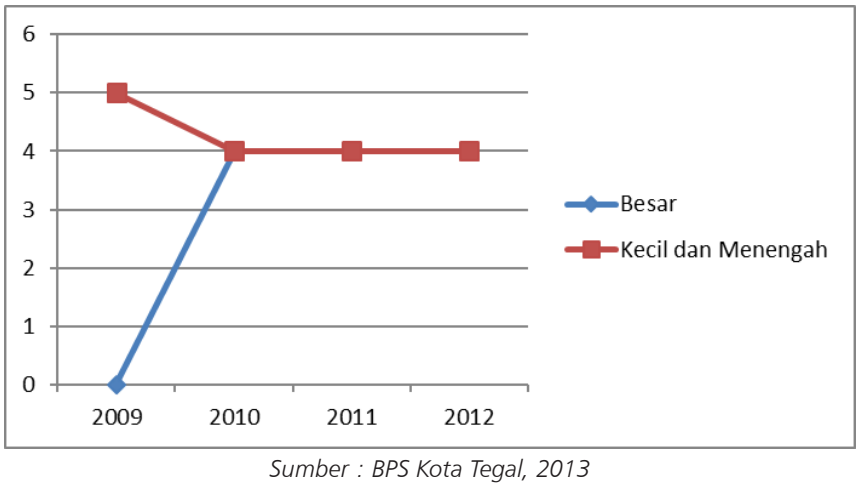

Melihat perkembangan nilai investasi dalam grafik 4, untuk investasi di Kota Tegal pada Tahun 2009 pasca ditetapkan kebijakan Tegal Bisnis mengalami kecenderungan nilai yang stabil pada industri besar dan kecil menengah. Maka persaingan antara industri Besar dan industri kecil menengah dapat dikatakan berimbang, sesuai dengan tujuan kebijakan Tegal Bisnis yakni menyeimbangkan nilai investasi. Namun berbanding terbalik dengan tujuan kebijakan yakni meningkatkan investasi, melihat grafik 4 nilai investasi mengalami keseimbangan dari tahun 2010 hingga 2012.

Berdasarkan uraian tiap-tiap subindikator yang telah dibahas, maka dapat diketahui mengenai tingkat produktifitas keseluruhan. 
Adapun klasifikasi penilaian terhadap tiap sub-indikator sebagai berikut.

TABEL 3. SKOR PRODUKTIVITAS

\begin{tabular}{lll}
\hline Indikator & Penilaian & Skor (\%) \\
\hline $\begin{array}{l}\text { Pendapatan Perkapita/Kesejahteraan } \\
\text { Masyarakat Industri }\end{array}$ & Tidak Efektif & 0 \\
\hline Lapangan pekerjaan & Tidak Efektif & 0 \\
\hline Kualitas Produksi & Efektif & 10 \\
\hline Meningkatkan Investasi Kota Tegal & Tidak Efektif & 0 \\
\hline Total & & 10 \\
\hline
\end{tabular}

Sumber : Data Primer 2013

Berdasarkan tabel 3, menunjukkan bahwa yang dijadikan tolak ukur Kebijakan Tegal Bisnis seperti pendapatan perkapita masyarakat industri, lapangan pekerjaan, kualitas produksi, dan nilai investasi Kota Tegal. dengan pemberian bobot pada indikator produktivitas sebesar 40\%. Maka didapati bahwa nilai indikator produktivitas sebagai berikut.

$$
\begin{aligned}
& \text { nilai indikator }=\frac{\text { nilai sub }}{\text { total sub }} \times \text { bobot indikator } \\
& \text { nilai indikator }=\frac{1}{4} x 40 \%=10 \%
\end{aligned}
$$

Berdasarkan hasil perhitungan menyebutkan bahwa sub-indikator kualitas produksi dinyatakan efektif, namun 3 sub-indikator lainnya dinyatakan tidak efektif. Oleh karena itu, kebijakan Tegal Bisnis dinilai tidak produktif karena mendapatkan skor sebesar $10 \%$.

\section{EFISIENSI}

Efisiensi menurut The Liang Gie dan Miftah Thoha menjelaskan bahwa suatu kegiatan dapat disebutkan efisien jika usaha yang telah dilakukan memberikan output yang maksimum, baik dari jumlah maupun kualitas. Suatu kegiatan juga dapat dikatakan efisien jika 
dengan usaha minimum dapat mencapai output tertentu. Efisien dalam kebijakan Tegal Bisnis dilihat melalui penggunaan sumber dana operasional yang dipakai sesuai dengan perencanaan kebijakan. Adapun sub-indikator tersebut seperti tingkat kesejahteraan masyarakat industri, kualitas produksi, dan investasi daerah. Untuk efektivitas dan efisiensi, ada beberapa hal yang perlu mendapat perhatian kita bersama. Beberapa hal dimaksud antara lain: (1) perlu ada kesamaan paham mengenai konsep pemberdayan, sebab pada akhir-akhir ini berbagai program/proyek pembangunan diberi lebel pemberdayaan, walaupun sebenarnya justru mengingkari makna pemberdayaan; dan (2) perlu ada koordinasi antarlembaga dan bahkan dalam lembaga dalam gerakan pemberdayaan ini, sebab ditengarai ada banyak kegiatan/proyek yang saling tumpang tindih dan mirip satu sama lain dengan nama yang berbeda (Bappenas:2000).

\section{A. TINGKAT KESEJAHTERAAN MASYARAKAT INDUSTRI}

Dalam meningkatkan kesejahteraan masyarakat industri Kota Tegal, pemerintah menyelenggarakan program seperti penyelenggaraan promosi produk UMKM dan sosialisasi kebijakan penyederhanaan dokument ekspor impor.

Dalam upaya pemerintah meningkatkan kesejahteraan masyarakat industri dari kegiatan a dan b melakukan efisiensi anggaran lebih dari 75\%. Maka dapat dikatakan efisien pada sub-indikator kesejahteraan masyarakat industri.

\section{B. PENINGKATAN KUALITAS PRODUKSI INDUSTRI DAN UMKM}

Pemerintah Kota Tegal dalam meningkatkan kualitas produksi UMKM memberikan program untuk pelaku industri kecil maupun menengah seperti fasilitasi kemitraan usaha, peningkatan kemampuan industri berbasis teknologi, dan fasilitasi pemanfaatan sumber daya. Pemberian program kepada masyarakat industri berasal dari pendanaan ABPD tahun 2012. Berdasarkan hasil temuan bahwa 
setiap kegiatan pada sub-indikator kualitas produksi melakukan efisiensi anggaran lebih dari 75\%, maka dapat dinyatakan efisien dalam indikator meningkatkan kualitas produksi UMK.

\section{MENINGKATKAN INVESTASI INDUSTRI DAERAH}

Dalam mengupayakan peningkatan investasi daerah Kota Tegal khususnya industri UMKM, pemerintah melalui kebijakan Tegal Bisnis memberikan beberapa kegiatan untuk menunjang peningkatan laju investasi Kota Tegal. Program yang telah dilaksanakan oleh pemerintah Kota Tegal yakni fasilitasi kerjasama UMKM dengan swasta, penyediaan sarana maupun prasarana klaster industri, penyediaan sarana informasi yang dapat diakses masyarakat, peningkatan pengawasan peredaran barang, sosialisasi ketentuan cukai, pengembangan pasar, dan penataan tempat usaha bagi PKL. Adapun pengukuran efisien anggaran diuraikan dalam tabel berikut.

Berdasarkan uraian tabel 6, menunjukkan bahwa kegiatan setiap sub-indikator melakukan efisiensi hingga 75\%, maka dapat dinilai efisien dalam meningkatkan laju investasi daerah. Melihat setiap uraian indikator efisiensi program yang telah dibahas sebelumnya, maka dapat dianalisis mengenai penilaian terhadap indikator efisiensi Kebijakan Tegal Bisnis sebagai berikut.

TABEL 6. EFISIENSI KEBIJAKAN TEGAL BISNIS

\begin{tabular}{lll}
\hline Indikator Anggaran & Kriteria & Bobot Nilai (\%) \\
\cline { 1 - 2 } Kesejahteraan Masyarakat industri UMKM & Efisien & \\
\cline { 1 - 2 } Peningkatan kualitas produksi & Efisien & \\
\cline { 1 - 2 } Investasi Daerah & Efisien &
\end{tabular}

Maka dapat diperoleh nilai bobot pada indikator efisien sebagai berikut.

Nilai indikator $=\%$

Berdasarkan analisis diatar menunjukkan bahwa sub-indikator yang dijadikan tolak ukur efisiensi Kebijakan Tegal Bisnis seperti 
kesejahteraan masyarakat industri umkm, peningkatan kualits produksi dan meningkatkan laju investasi daerah dapat dikatakan efisien dengan bobot standar 30\%.

TABEL 7 IKM KEBIJAKAN TEGAL BISNIS 2012

\begin{tabular}{|c|c|c|}
\hline Unsur Kepuasan & Nilai IKM & Mutu Baku \\
\hline Fasilitas Pameran Industri & 3,38 & A \\
\hline Sosialisasi Kebijakan Ekspor & 2,46 & C \\
\hline Sosialisasi Pinjaman Kredit & 3,41 & A \\
\hline Materi Pelatihan Diklat & 3,43 & A \\
\hline Fasilitas Pelatihan & 3,05 & B \\
\hline Bantuan Peralatan dan Bahan Baku Industri & 3,28 & A \\
\hline Sosialisasi Kebijakan Tegal Bisnis 2012 & 2,56 & B \\
\hline Pembuatan liji Usaha Industri & 2,31 & $\mathrm{C}$ \\
\hline Fasilitas Tempat Baru PKL & 2,58 & $B$ \\
\hline Ketertiban Alun-Alun & 2,55 & B \\
\hline Pemberian Papan Nama Industri & 2,28 & C \\
\hline Fasilitas Pasar Pagi & 2,53 & B \\
\hline Kenyamanan Pengunjung Pasar Pagi & 2,66 & $B$ \\
\hline Keamanan Pasar Pagi & 1,85 & D \\
\hline Nilai Indeks Kepuasan & 2,74 & \\
\hline Nilai IKM konversi = nilai indeks $\times$ nilai dasar 2,74 × 25 & 68,54 & \\
\hline Mutu Kebijakan & $B$ & \\
\hline Kinerja Kebijakan & Baik & \\
\hline
\end{tabular}

Sumber : Olah Data Penelitian 2013

\section{TINGKAT KEPUASAN MASYARAKAT}

Menurut Campble dalam mengevaluasi kebijakan pemerintah perlu ada respon dari masyarakat mengenai implementasi kebijakan. Respon masyarakat merupakan tingkat kepuasan yang dirasakan oleh masyarakat penerima kebijakan. Untuk mengetahui tingkat kepuasan masyarakat terhadap kebijakan yang telah ditetapkan, maka sebagai indikator kepuasan ialah capaian target yang telah ditetapkan oleh pemerintah dalam kebijakan. Target kebijakan Tegal Bisnis yakni pertumbuhan kesejahteraan masyarakat industri, meningkatkan kualitas produksi UMKM dan industri, dan 
meningkatkan laju investasi daerah. Adapun hasil perhitungan indeks kepuasan masyarakat dari setiap unsur kepuasan masyarakat maka dihasilkan nilai IKM sebagai berikut :

Berdasarkan tabel 7 menunjukkan bahwa rata-rata indeks nilai pada kebijakan Tegal Bisnis adalah 2,74. Indeks nilai tertinggi terdapat pada unsur ke 4, yaitu mengenai materi pelatihan/diklat yang mencapai 3,41. Sedangkan indeks nilai terendah terdapat pada unsur ke 14, yaitu keamanan pasar dengan indeks nilai sebesar 1,85.

Dari 14 unsur yang dikaji,terdapat nilai IKM sebesar 68,54\% dengan mutu kebijakan kategori B (kinerja baik), yaitu kenyamanan pengunjung pasar pagi, fasilitas pasar pagi, ketertiban alun-alun,fasilitas tempat baru PKL, sosialisasi kebijakan Tegal bisnis, pemberian bantuan peralatan, fasilitas pelatihan, materi pelatihan, sosialisasi kredit/pinjaman lunak, dan fasilitas pameran industri.

Untuk menentukan urutan prioritas unsur-unsur kebijakan yang perlu ditingkatkan kualitas kinerjanya dalam upaya meningkatkan kepuasan masyarakat atas kinerja kebijkan maka dilakukan analisis kesesuaian harapan dan kenyataan (Importance-Performance Analysis). Hasil analisis menyatakan bahwa unsur sosialisasi kebijakan ekspor, proses pembuatan ijin usaha, pemberian papan petunjuk wilayah industri, dan keamanan pasar pagi.

\section{KESIMPULAN}

Kebijakan kesejahteraan masyarakat merupakan tanggung jawab pemerintah yang harus diberikan perhatian khusus. Tegal Bisnis merupakan salah satu kebijakan pemerintah Kota Tegal dalam mengupayakan kesejahteraan masyarakanya melalui program peningkatan mutu bisnis masyarakat. Adapun dampak yang ditimbulkan oleh kebijakan tersebut dapat dilihat dari 3 (tiga) aspek yaitu Produktivitas kebijakan, efisien kebijakan, dan kepuasan masyarakat tentang kebijakan.

Berdasarkan penelitian yang telah dilakukan bahwa produktivitias 
yang dihasilkan oleh kebijakan Tegal Bisnis sangat rendah hal ini disebabkan karena pemerintah tidak seimbang dalam memberikan fasilitas pelatihan dan sosialisasi pemerintah mengenai perizinan usaha masyarakat. Walaupun pemerintah dalam menggunakan pendanaan untuk kebijakan Tegal bisnis sangat efisien karena hampir semua anggaran terserap sesuai dengan perencanaannya. Namun bukan berarti dengan adanya kebijakan Tegal Bisnis masyarakat kesejahteraan masyarakat akan meningkat berdasarkan penelitian bahwa kesejahteraan masyarakat tidak meningkat dan masyarakat tidak puas dengan kebijakan Tegal Bisnis.

\section{DAFTAR PUSTAKA}

\section{BUKU}

Druker, Peter F, 1989. The New Realities. Jakarta : PT. Elek Media Komputindo.

Dunn, William, N. 2003. Analisis Kebijakan Publik. Yogyakarta : Gadjah Mada University Press.

Edward III, George C., 1980, Implementing Public Policy, Washington : Congressional Quarterly, Inc.

Effendi, Sofian, 1990. Kebijakan Publik Berwawasan Pemerataan, dalam buku : "Beberapa Aspek Pembangunan Orde Baru". Rhamadhani, Solo.

Effendi, Sofian, dkk. 2012. Metode Penelitian Survei. Jakarta : LP3ES.

Fadliilah, Diah Nur. 2012. Skrispi: Analisis Penyerapan Tenaga Kerja Pada Industri Kecil. UNDIP.

Gibson, James L., Ivancevich, John M. Donnely Jr. James H. 1995. Organisasi Dan Manajemen. Perilaku Struktur Proses, Alih Bahasa : Wahid, Djoerban, Jakarta: Erlangga.

Hadi, Samsul. Dr. dkk, 2011. Metode Riset Evaluasi. Yogyakarta: Laksbang Grafika.

Islamy, M. Irfan, 1984. Prinsip - prinsip Perumusan Kebijaksanaan Negara, Bumi Aksara : Jakarta.

Kusumanegara, Solahuddin. 2010. Model dan Aktor Dalam Proses Kebijakan Publik. Yogyakarta:Gava Media.

Kotler Philip-Amstrong (2003), Manajemen Pemasaran,-,Salemba Empat, Jakarta.

Lane. 1993. The Public Sector : Concept, Models and Approaches. Jakarta : PT Elek Komputindo.

Maryono, Erfan. 2006. Studi Evaluasi Pelaksanaan Program KompensasiPengurangan Subsidi Bahan Bakar Minyak Bidang Infrastruktur Perdesaan. Jakarta: LP3ES.

Mazmanian, Daniel and Sebatier, Paul (eds). 1981. Efective Policy Implementation. Lexington, Mass, D.C. Heath. 
Moleong, Lexy J. 2007. Metodologi Penelitian Kualitatif. Bandung : PT Remaja Rosdakarya. Nugroho, Riant. 2012. Public Policy. Jakarta : PT Elek Komputindo

Pusdiklat Renbang OTO-Bappenas. 2000. Laporan Akhir Studi tentang Evaluasi Dampak Program Pelatihan Teknik dan Manajemen Perencanaan Pembangunan Tingkat Dasar (TMPPD). Jakarta : Bappenas.

Subarsono. 2010. Analisis Kebijakan Publik. Yogyakarta : Pustaka Pelajar.

Suharto, Edi. 2010. Analisis Kebijakan Publik. Bandung: Alfabeta.

Suyanto, Bagong, dkk. 2006. Metode Penelitian Sosial. Jakarta : Kencana Prenada Media Group.

Singarimbun, Masri. Sofian Efendi. Metode Penelitian Survey. Jakarta : LP3ES.

Siagian. Sondang. P. 2006. Manajemen Modern. Gunung Agung : Jakarta.

Siregar. Dolly. 2006. Management Aset Daerah. Gramedia: jakarta.

Todaro, Michael, P. 2000. Pembangunan Ekonomi di Dunia Ketiga, Erlangga. Jakarta. Tadjoeddin, 2011. Ekonomi Islam. Tiara Wacana : Yogyakarta

Wahab, Solichin Abdul, 2002, Analisis Kebijaksanaan : dari Formulasi ke Implementasi Kebijaksanaan Negara, Jakarta:Sinar Grafika.

1990. Pengantar Analisis Kebijaksanaan Negara, Jakarta : Rineka

Cipta.

1990. Analisis Kebijaksanaan Dari Formulasi ke Implementasi

Kebijaksanaan Negara, Jakarta: Bumi Aksara.

1994. Esensi Nilai Dalam Kebijkana Perbincangan Teoritikal, dalam

buku "Kebijakan Publik \& Pembangunan", IKIP Malang.

Winarno, Budi. 2012. Kebijakan Publik (Teori, Proses, dan Studi Kasus). Yogyakarta : CAPS.

2008. Kebijakan Publik. Yogyakarta : MedPress.

\section{JURNAL}

Dwi Kurniawan, Bachtiar. 2011. Implementasi Kebijakan Sertifikasi Guru dalam Rangka Meningkatkan Profesionalitas Guru di Kota Yogyakarta. Journal of Government and Politicts. Volume 2 Nomor 2 Agustus 2011.

Karsidi, Ravik. 2007. Pemberdayaan Masyarakat untuk Usaha Kecil dan Mikro (Pengalaman Empiris di Wilayah Surakarta Jawa Tengah). Jurnal Penyuluhan, September 2007, Vol. 3 No. 2

Rifa'I, Bachtiar. 2013. Efektifitas Pemberdayaan Usaha Mikro Kecil dan Menengah (UMKM) Krupuk Ikan dalam Program Pengembangan Labsite Pemberdayaan Masyarakat Desa Kedung Rejo Kecamatan Jabon Kabupaten Sidoarjo. Jurnal Kebijakan dan Manajemen Publik Universitas Airlangga. Volume 1 Nomor 1, Januari 2013.

Sopandi, Andi. 2010. Strategi Pemberdayaan Masyarakat: Studi Kasus Strategi Dan Kebijakan Pemberdayaan Masyarakat di Kabupaten Bekasi. Jurnal Kybernan, Vol. 1,. 1 Maret 2010.

Yatmo Hutomo, Mardi. 2000. Pemberdayaan Masyarakat dalam Bidang Ekonomi: Tinjauan Teoritik dan Implementasi. Bappenas : Naskah No. 20, Juni-Juli 2000. 